\title{
OCCUPATIONAL AND PUBLIC HEALTH. THE WRINKLE RECOVERY ANGLE (WRA) STUDY OF FABRIC THAT NANO-SILVER TREATED
}

\author{
A. M. Pirzada ${ }^{1 *}$, S. Vambol ${ }^{2}$, Z. Khatri ${ }^{3}$, A. Aziz ${ }^{1}$, N. A. Samoon ${ }^{1,}$ S. Shaikh ${ }^{3}$, M. Ali ${ }^{3}$, S. Sikandar $^{3}$ \\ ${ }^{1}$ Sindh Madressatul Islam University, Karachi, Pakistan \\ ${ }^{2}$ Kharkiv Petro Vasylenko National Technical University of Agriculture, Kharkiv, Ukraine. \\ ${ }^{3}$ Mehran University of Engineering and Technology, Jamshoro, Pakistan \\ *Corresponding email: ampirzada@smiu.edu.pk
}

Received: 18 February 2020; Accepted: 21 March 2020

Cite as: Pirzada, A.M., Vambol, S., Khatri, Z., Aziz, A., Samoon, N.A., Shaikh, S., Ali, M., Sikandar, S. (2020). Occupational and Public Health. The wrinkle recovery angle (WRA) study of fabric that nano-silver treated. Labour Protection Problems in Ukraine, 36(1), 3-11.

The constant use of wrinkle-resistant cellulose fabrics in professional and everyday life can negatively affect the health state. This is because formaldehyde vapours, which contribute to allergies, persistent coughing, and irritation of the eyes, nose, and throat, sleep disturbances, headaches, etc., pose a greater danger. In this study an attempt was made to achieve fabric stabilization from wrinkle resistant by formation ionic bonds of as replacement covalent bonds. And this is the main study purpose. Industrially Desized and Bleached $100 \%$ pure cotton fabric with the weight of 110 $\mathrm{g} / \mathrm{m}^{2}$, and the chemicals were used. Preparation of cationic glycerine, carboxymethylation of bleached fabric and application of antimicrobial finishes on the ionic cross-linked fabric was provided. Measurements were taken to determine of wrinkle recovery angle (WRA), of absorbency, of whiteness index, of flexural rigidity, of abrasion, of tensile strength. Wrinkle recovery angle was measured by standard method of AATCC 66 (option 2). AATCC Test Method 79-2000 was used to test the absorbency of fabric. The CIE whiteness index was determined using an Xrite Colour Eye 7000A spectrophotometer. Flexural Rigidity was measured through a testing cantilever method ASTM D-1388. Fabric abrasion was checked according to standard method for abrasion resistance of textile fabric ASTM 4966 on Martindale Abrasion Device M235. Mechanical strength of the fabric was measured under the standard method of ASTM D-5034. With the ionic cross-linking, the dry WRA was achieved an optimum of $118^{\circ}$ and wet WRA up to $128^{\circ}$ with increased fabric strength and whiteness. In addition to ionic cross-linking fabric was treated with Nano silver. Based on the results it was concluded that the fabric can be optimized first with ionic cross-link method and then it can be treated with the antimicrobial making the fabric cleaner and hygienic. This fabric treatment provides the necessary characteristics and is safe for the health of the people who use it.

Keywords: occupational and public health; textile products safety; wrinkle recovery angle; cationic glycerine; ionic cross-link method; treatment with Nano silver.

\section{ГІГІЄНА Й ОХОРОНА ЗДОРОВ'Я. ДОСЛІДЖЕННЯ КУТА ВІДНОВЛЕННЯ СКЛАДОК (WRA) ТКАНИНИ, ОБРОБЛЕНОЇ НАНОСРІБЛОМ}

\author{
А. М. Пірзада ${ }^{1 *}$, С. Вамболь ${ }^{2}$, 3. Кхатрі ${ }^{3}$, А. Азіз ${ }^{1}$, Н. А. Самоон ${ }^{1}$, С. Шаікх ${ }^{3}$ М. Алі ${ }^{3}$, С. Сікандар ${ }^{3}$ \\ ${ }^{1}$ Університет Сінд Мадрессатул Айлама, Карачі, Пакистан \\ ${ }^{2}$ Харківський національний технічний університет сільського господарства імені Петра Василенка, Харків, Україна \\ ${ }^{3}$ Мехранській інженерно-технічний університет, Джамшоро, Пакистан \\ *E-mail для листування: ampirzada@smiu.edu.pk \\ Отримано: 18 Лютого 2020; Прийнято: 21 Березня 2020
}

Цитувати як: Pirzada, A.M., Vambol, S., Khatri, Z., Aziz, A., Samoon, N.A., Shaikh, S., Ali, M., Sikandar, S. (2020). Occupational and Public Health. The wrinkle recovery angle (WRA) study of fabric that nano-silver treated. Labour Protection Problems in Ukraine, 36(1), 3-11.

Постійне використання стійких до складок целюлозних тканин у професійному й повсякденному житті може негативно позначитися на стані здоров'я. Адже пари формальдегіду спричиняють алергію (постійний кашель, подразнення очей, носа і горла), порушення сну, головні болі тощо, і тим самим становлять велику небезпеку. У цьому дослідженні було зроблено спробу стабілізації стійкості тканини до складкам шляхом утворення іонних зв'язків на заміну ковалентним зв'язкам. І це основна мета дослідження. Для дослідження була використана промислово оброблена і вибілена $100 \%$-во чиста бавовняна тканина щільністю 110 г/м ${ }^{2}$ і різні хімічні речовини. Було забезпечено приготування катіонного гліцерину, карбоксиметілірування вибіленої тканини і нанесення антимікробних покриттів на зшиту іонами тканину. Вимірювання були проведені для визначення кута відновлення складок (WRA), вологопоглинання, білизни, жорсткості при згині, стирання, міцності на розрив. Кут відновлення складок вимірювали стандартним методом ААТСС 66 (варіант 2). Метод випробування AАТCC 79-2000 був використаний для перевірки здатності тканини вбирати вологу. Індекс білизни СІЕ визначали 3 використанням спектрофотометра Xrite Color Еуе 7000A. Жорсткість при згині вимірювали за допомогою випробувальної консолі методом ASTM D-1388. Стирання тканини перевіряли відповідно до стандартну методу стійкості до стирання текстильної тканини ASTM 4966 на пристрої для абразивного зносу Martindale M235. Механічна міцність тканини вимірювалася за стандартним методом ASTM D-5034. Завдяки утворенню іонних поперечних зв'язків WRA сухої тканини досяг оптимального значення $118^{\circ}$, а вологої - до $128^{\circ} 3$ підвищеною міцністю і білизною тканини. На додаток до утворення іонних поперечних зв'язків тканина була оброблена наносріблом. На підставі отриманих результатів було зроблено висновок, що спочатку тканину можна оптимізувати методом іонного зшивання, а потім обробити антимікробним засобом, що робить тканину більш чистою і гігієнічною. Така обробка тканини забезпечує необхідні характеристики і безпечна для здоров'я людей, які її використовують.

Ключові слова: гігієна праці й охорона здоров'я; безпека текстильних виробів; кут відновлення складок; катіонний гліцерин; метод іонних поперечних зв'язків; оброблення наносріблом.

1. Problem statement and analysis of the recent researches and publications.

Textile products (both professional and casual wear) are preferably cellulosic, and more preferably cotton based. Cotton fabrics show a tendency to wrinkle. Therefore, in recent years, the demand for wrinkle-resistant cellulose fabrics has increased. Although cleaning and care of such fabrics is simplified, some wearers experience decreased comfort.

The cross-linkers N-methylol have the significant use as the durable press finishing, because they provide fabric crease 
resistance, anti-curl, shrinkage resistance and durable press. However they are considered as a human carcinogen finish due to release of formaldehyde content and also weaken the strength [1]. One of the several options for the possible treatment for cotton fabrics is durable press finish, these ensure that the clothes are resistant to wrinkles and also have press performance for comparatively long-lasting time. The cellulose chains in the fabric are strengthening through the formation of covalent bonds that are cross-linked together and these covalent bonds are not disrupted by water [2]. Conventional durable press involves two kinds of items which include reactant and resin. They both contain formaldehyde which is a human carcinogen [3].

As you know, carcinogens have the ability to change DNA, that is, the genetic code of a living cell. Damage to specific sections of DNA causes a violation of the mechanisms for controlling the rate of cell division and their differentiation, which can contribute to the formation of a tumour. It is known that carcinogens provide diseases in humans with prolonged exposure. Consequently, the constant use of wrinkle-resistant cellulose fabrics in professional and everyday life can negatively affect the health state. Formaldehyde directly on the skin causes only local irritation, which quickly stops. However, formaldehyde vapours, which contribute to allergies, persistent coughing, irritation of the eyes, nose, throat, sleep disturbances, headaches, etc., pose a much greater danger.

In the same time, there are durable press finishes that do not contain formaldehyde or formaldehyde precursors. Formaldehyde may be replaced by various types of chemicals such as Dihydroxy Dimethyl Imidazolidinone (DHDMI), Dimethyl Dihydroxy Ethylene Urea (DMDHEU), 1 polycarboxylic acids for example citric acid and butane tetra carboxylic acid, with hypophosphite salts, imidazoles or sodium maleate, sodium tartrate or sodium citrate as catalysts, and citric acid as extender. In addition to the above mention chemicals it is also proposed to use systems which are based on silicones polyacrylics and polyurethane. Reactive polymeric silicones appeal interest as they provide in tandem facets such as making the fabric waterproof, noncreasing and possessing soil-release properties. From an economic perspective the finishing systems which use zero formaldehyde do not find favour as compared to the DMDHEU type product due to their inflated cost. The final cost can be reduced by using feasible additives which include among others phosphorous catalysts sodium salt of hydroxyl acids or polyhydric alcohols. However, using these alternatives resultantly weakens the fabric strength, makes the fabric more yellowish and affects the finishing making it less long lasting [2-4].

It is clear that the manufacturing of non-formaldehyde by using different types of common and available chemicals is mandated. Therefore, scientists are continuously working on making use of ionic cross-linking as a substitute method for delivering durable press performance $[5,6]$ elaborated an ionic cross-linking procedure, in which cotton is added by an ionic site and then it will cross-linked by using a polyion which is opposite charges. In a previous study, [7] cellulose reacted with chloroactic acid (CAA) and then cross-linked it with cationic chitosan, cationic glycerine (CG), calcium chloride, magnesium chloride, cationized ethylene glycol, cationized dextrose, cationized D-celobiose and cationized $B$ cyclodextrin and then cellulose reacted with 3-chloro-2hydroxypropyl-trimethyl ammonium chloride (CHTAC) and cross-linked it with polycarboxylic acid (PCA), 1,2,3,4butanetetracarboxylic acid (BTCA), ethylene diamine tetraacetic acid (EDTA), nitrilo riacetic acid trisodium salt monohydrate (NTA), N-(2-hydroxyethyl) ethylene dinitrilo triacetic acid (HEDTA), oxalic acid, citric acid and maleic acid. These all of the cross-linking agents exhibited improved results in wrinkle resistance but the higher wrinkle recovery angle (WRA) results are obtained when carboxymethylated (anionic) cotton is reacted with cationic agents synthesized by reaction of a quaternary compound, CHTAC, with chitosan or glycerine. There is no formaldehyde release or loss in strength unlike conventional methods and WRA results because such treated cotton fabric is encouraging, but yet an optimized procedure for ionic cross-linking is still demanded. Reduction in energy and chemical usage as well as strengthening in fabric properties are some of the positives of using quaternary compounds in textile industry [8-14].

Since occupational and public health is a priority, the use of hazardous and harmful components in tissues for professional and everyday use should be avoided. To fulfill the increasing demand of clean, comfortable, hygienic and durable press fabric need of antimicrobial finishes has risen and different antimicrobial chemicals have been discovered and selected due to their aesthetic properties. Nano-Particles have been used for equal distribution of the chemicals on the surface of the fabric. These particles required to be equal in size and shape and should be stable against agglomeration.

In this study an attempt was made to achieve fabric stabilization from wrinkle resistant by formation ionic bonds of as replacement covalent bonds. And this is the main study purpose.

The step of producing anionic cellulose and cationization of glycerine was adopted from previous research [15] keeping the concentration of sodium salt of chloroacetic acid same with the varying concentration of glycerine that has to be cationised. Process parameters were kept same throughout the whole process. Ionic cross-linking was carried out by treating cotton fabric with sodium salt of chloroacetic acid, whereas cationic glycerine was obtained by reaction of glycerine with cationic agent i.e. CHTAC (3-chloro-2-hydroxypropyl-trimethylammoniumchloride). This cross-linked fabric was then treated with the Nano-Silver chemical with different concentrations: $(10 \mathrm{~g} / \mathrm{L}, 15 \mathrm{~g} / \mathrm{L}$ and $25 \mathrm{~g} / \mathrm{L})$ with the addition of binder i.e. Appretan N 92111 [16]. The process success was estimated by assessing the Wet and dry wrinkle recovery angles and tensile strength. The increase in wet wrinkle recovery angle (WRA) is important for applications like bedding and this treatment showed an improvement along with the increase in tensile strength. It was also observed that the fabric weight was increased hence producing a Hand Building Effect.

\section{Statement of the problem and its solution.}

\subsection{Materials.}

In this study, industrially Desized and Bleached $100 \%$ pure cotton fabric with the weight of $110 \mathrm{~g} / \mathrm{m}^{2}$, were used and the chemicals used in this research were Chloro acetic acid $\left(\mathrm{ClCH}_{2} \mathrm{COOH}\right)$, Sodium carbonate $\left(\mathrm{Na}_{2} \mathrm{CO}_{3}\right), \quad \mathrm{CR}-2000$ (CHTAC), Glycerine, Sanitized T 27-22 silver Nano silver and Appretan N 92111 (Binder) were provided by the Dow chemical company and Clariant Pakistan.

\subsection{Methods.}

Carboxymethylation of bleached fabric. Choro acetate solution was prepared by neutralizing the mono chloroacetic acid with a weak base like sodium carbonate etc. The mono chloroacetic acid flakes of weight 189 grams were dissolved in deionized water. $106 \mathrm{~g}$ of Sodium Carbonate was also dissolved in deionized water. Both solutions were then mixed together to make a solution of $1 \mathrm{~L}$ of $2.0 \mathrm{M}$ concentration. Carbon dioxide was evolved in the reaction as mono chloroacetic acid neutralized. Due to precipitation of Carbon dioxide, preparation of chloroacetate was carried into Chemical Fume Hood. The fabric was then soaked in $17.14 \%$ of caustic 
soda $(\mathrm{NAOH})$ using liquor ratio $(1: 30)$ for 10 minutes and then padded to a wet pick up of $100 \%$ and then dried at $60{ }^{\circ} \mathrm{C}$ for 10 minutes

The fabric was treated with chloroacetate by soaking them in the solution with a liquor ratio of $1: 30$. It was soaked in a $1.0 \mathrm{M}$ aqueous solution of chloroacetate. The fabric was left in the solution for 5 minutes at room temperature. It was padded to approximately $100 \%$ WPU (wet pick up). The fabric was then placed in a polyethylene bag and the air was removed from the bag. It was held in the sealed bag at $70{ }^{\circ} \mathrm{C}$ for one hour. After one hour, the fabric was rinsed with hot tap water three times and cold tap water once. It was then treated with a $2 \mathrm{~g} / \mathrm{L}$ acetic acid solution. Finally, it was rinsed with cold deionized water three times. The fabric was then centrifuged and dried at room temperature for 24 hours without tension.

Preparation of cationic glycerine. 1156 g CR-2000 solution of concentration $69 \%$ was taken. $228 \mathrm{~g}$ of $\mathrm{NaOH}$ solution was added into CR-2000 solution drop wise for acidity to reach $\mathrm{pH} 10-11$. A large quantity of $\mathrm{NaCl}$ was precipitated from the solution. The solution was then filtered through filter paper to remove excessive amount of salt. Glycerine was mixed to this solution at a mole ratio of 1 mole of glycerine to $8.0 \mathrm{M}$ of CR-2000. The Mixture stirred for 10 minutes at room temperature and was moved to a preheated water bath where it was held at $60{ }^{\circ} \mathrm{C}$ for 18 hours with agitation. The solution gradually became viscous. The product obtained was then cooled at room temperature and the final solution acidity was $\mathrm{pH} 7$.

The anionic cellulosic fabric was obtained by carboxymethylation method which was soaked in cationized glycerine solution of varying concentrations $(2 \%, 3 \%$ and $5 \%$ ) using Pad-dry-cure method. The negative charges on the cellulose formed ionic bonds with the positive charges on the cationized glycerine forming ionic cross-links.

Application of antimicrobial finishes on the ionic crosslinked fabric. The optimized fabric samples was padded separately with different concentrations of commercial Product (Sanitized® T 27-22 silver) (10 g/L, $15 \mathrm{~g} / \mathrm{L}, 25 \mathrm{~g} / \mathrm{L}$ ) and Appretan N 92111 (binder), keeping a $65 \%$ expression. The padded fabric samples were then dried at $80-85^{\circ} \mathrm{C}$ to maintain the residual moisture content of $8-10 \%$. The dried fabric samples were cured at $140{ }^{\circ} \mathrm{C}$ temperature.

\subsection{Measurements.}

Wrinkle Recovery Angle. Wrinkle Recovery Angle was measured by standard method of AATCC 66 (option 2). The fabric samples were conditioned under standard humidity conditions and then tested on Shirley Wrinkle Recovery Angle Tester.

Absorbency. AATCC Test Method 79-2000 was used to test the absorbency of fabric. Distilled water and burette, stand and embroidery ring was used as an apparatus.

Whiteness Index. The CIE whiteness index was determined using an Xrite Color Eye 7000A spectrophotometer. The samples were folded four times and a LAV aperture was used. Each sample was measured two times with two different locations between each test. The average of the two results was taken for each sample.

Flexural Rigidity. It was measured through a testing cantilever method ASTM D-1388. The fabric was cut according to the size of test specimen. The bending length was measured on cantilever instrument. The flexural rigidity was measured by equation

$$
\mathrm{G}=\mathrm{W} \times \mathrm{L}_{3} .
$$

Abrasion. Fabric abrasion was checked according to standard method for abrasion resistance of textile fabric ASTM 4966 on Martindale Abrasion Device M235. The fabric was checked on 5000 revolutions under the speed of $50 \mathrm{rpm}$, the weight used was $9 \mathrm{kPa}$.

Tensile Strength. Mechanical strength of the fabric was measured under the standard method of ASTM D-5034.

2.4. Results and Discussion.

All the fabric samples were tested under standard conditions and various properties were determined for the fabric treated with cationic glycerine with varying concentration $2 \%, 3 \%$ and $5 \%$ and Nano-Silver application with Binder and without Binder. The effects on these properties are summarized by such factors as:

- Dry and Wet Wrinkle Recovery Angle;

- CIE Whiteness Index;

- Effect of Cationic Glycerine Concentration on CIE Whiteness Index; Index

- Effect of Nano-Silver Concentration on CIE Whiteness

- Absorbency;

- Flexural Rigidity;

- Tensile Strength;

- Abrasion.

Dry and Wet Wrinkle Recovery Angle. The results for the WRA of untreated fabrics are shown in Figure 1a. WRA were determined separately to verify that the same trends were observed in both sets of data. It was observed that the pad dry cure method has shown better results of dry WRA as compared to pad dry post cure method. The dry WRA increases up to $68.5 \%$ when the samples were post cured at the stage of ionic cross-linking as shown in the Figure 1d and Figure 2a.

It has been observed that concentration of cationic glycerine has considerable effects on dry WRA. It was investigated that the WRA of the fabric treated with $2 \%$ glycerine has greater angle then the other quantities of glycerine i.e. $3 \%$ and $5 \%$. So it was concluded as the concentration of cationic glycerine increases from $2 \%$ to $5 \%$ there is a decrease in dry WRA as mentioned in Figure 1b, Figure 1c, Figure 1d and Figure 2a. The highest dry WRA is achieved at $5 \%$ and least dry WRA is achieved at $2 \%$. The WRA was accessed after the application of Nano-Silver and Binder with varying concentrations i.e. $10 \mathrm{~g} / \mathrm{L}, 15 \mathrm{~g} / \mathrm{L}$ and $25 \mathrm{~g} / \mathrm{L}$ of Nano-Silver and concentration of Binder kept constant. It has been seen that Wrinkle recovery angle has indirect effect with the concentration of Nano-Silver because as the concentration of Nano-Silver is increased it affects the Wrinkle recovery angle in negative way, thus reducing the Wrinkle recovery angle of the samples as plotted in Figure 1c and Figure 2a.

It has also been investigated that with the application of binder i.e. Appretan N 92111 the WRA is also increased, hence it can be concluded that Binder works as a supporting ionic cross-linker, and making the cross-link stronger.

The WRA was determined separately to verify that the same trends were observed in both sets of data. It was observed that the pad dry post cured method have shown better results of wet WRA as compared to pad dry cure method. The wet WRA increases up to $82.5 \%$ when the samples were post cured at the stage of ionic cross-linking as shown in the Figure 3a. It has been observed that concentration of cationic glycerine has considerable effects on WET WRA. It was investigated the Wrinkle recovery angle of the fabric treated with $2 \%$ glycerine has greater angle then the other quantities of glycerine i.e. $3 \%$ and $5 \%$. The results have been extracted from Figure $2 b$, Figure 2c, Figure 2d and Figure $3 \mathrm{a}$. 

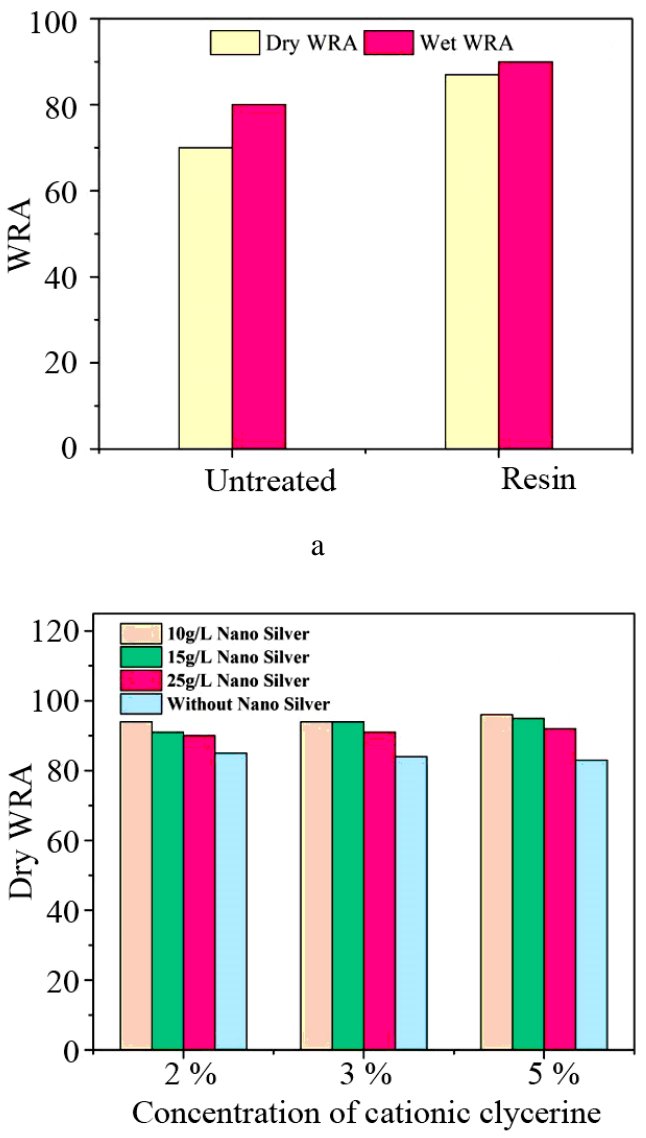

c

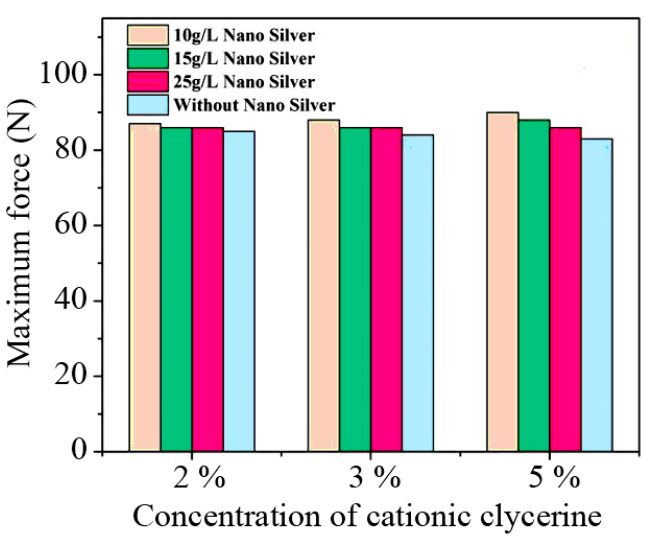

b

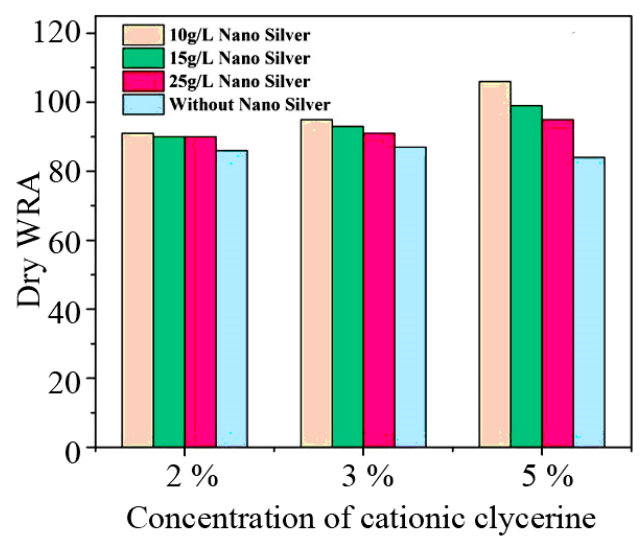

d

Figure 1 - The results for the WRA of untreated and treated fabrics: a - wrinkle recovery angle; $b$ - Dry WRA of Pad Dry Post Cure Samples without Appretan N 92111 with varying concentration of CG and Nano silver; c - Dry WRA of Pad Dry Post Cure Samples with Appretan N 92111 with Varying Concentration of CG and Nano silver; d - Dry WRA of Pad Dry Cure Samples without Appretan N92111 with Varying Concentration of CG and Nano silver

So it was concluded as the concentration of cationic glycerine increases from $2 \%$ to $5 \%$ there is a decrease in WET WRA. The highest WET WRA is achieved at $5 \%$ and least WET WRA is achieved at $2 \%$. The wet Wrinkle recovery angle was accessed after the application of NanoSilver and Binder with varying concentrations i.e. $10 \mathrm{~g} / \mathrm{L}$, $15 \mathrm{~g} / \mathrm{L}$ and $25 \mathrm{~g} / \mathrm{L}$ of Nano-Silver and concentration of Binder kept constant. It has been seen that wet Wrinkle recovery angle has indirect effect with the concentration of Nano-Silver because as the concentration of Nano-Silver is increased it affects the Wrinkle recovery angle in negative way, thus reducing the Wrinkle recovery angle of the samples. It has also been investigated that with the application of binder i.e. Appretan N92111 the Wrinkle recovery angle is also increased, hence it can be concluded that Binder works as a supporting ionic cross-linker, and making the cross-link stronger. These results can be seen in Figure 2c and Figure $2 \mathrm{~d}$.

CIE Whiteness Index. CIE Whiteness index was determined for the fabric treated with cationic glycerine with varying concentration $2 \%, 3 \%$ and $5 \%$ and Nano-Silver application with Binder and without Binder.

Effect of Pad Dry Cure and Pad Dry Post Cure Method on CIE whiteness Index

It has been evaluated that the pad dry post cure samples have shown high results then pad dry cure process. It is due to because curing process has inverse effect on whiteness index of the fabric, experimentally in pad dry cure process, the curing of fabric was carried out twice i.e. after the ionic cross-linking and after the application of Nano silver, where as in pad dry post cure process curing was carried out only after the application of Nano silver. The results are shown in Table 1 and Table 2.

Effect of Cationic Glycerine Concentration on CIE Whiteness Index. As the concentration of cationic glycerine increases, it has no effect on the white index of the fabric. Although the parameters when varied after the ionic crosslinking method as discussed above has considerable effect on the whiteness index of the fabric but there is no significant change in the value of whiteness index of the fabrics in which the concentration of the cationic glycerine has been varied as mentioned in Table 1 and Table 2.

Effect of Nano-Silver Concentration on CIE Whiteness Index. The samples which treated together with binder shows less whiteness index than the samples which were treated without binder i.e. Appretan N 92111 (binder). So it has been practically observed that the whiteness index decreases due to the binder. it was also experimented that Nano silver does not affect the whiteness index of the samples significantly, which are treated with different concentration of cationic glycerine given below in Table 2 . 

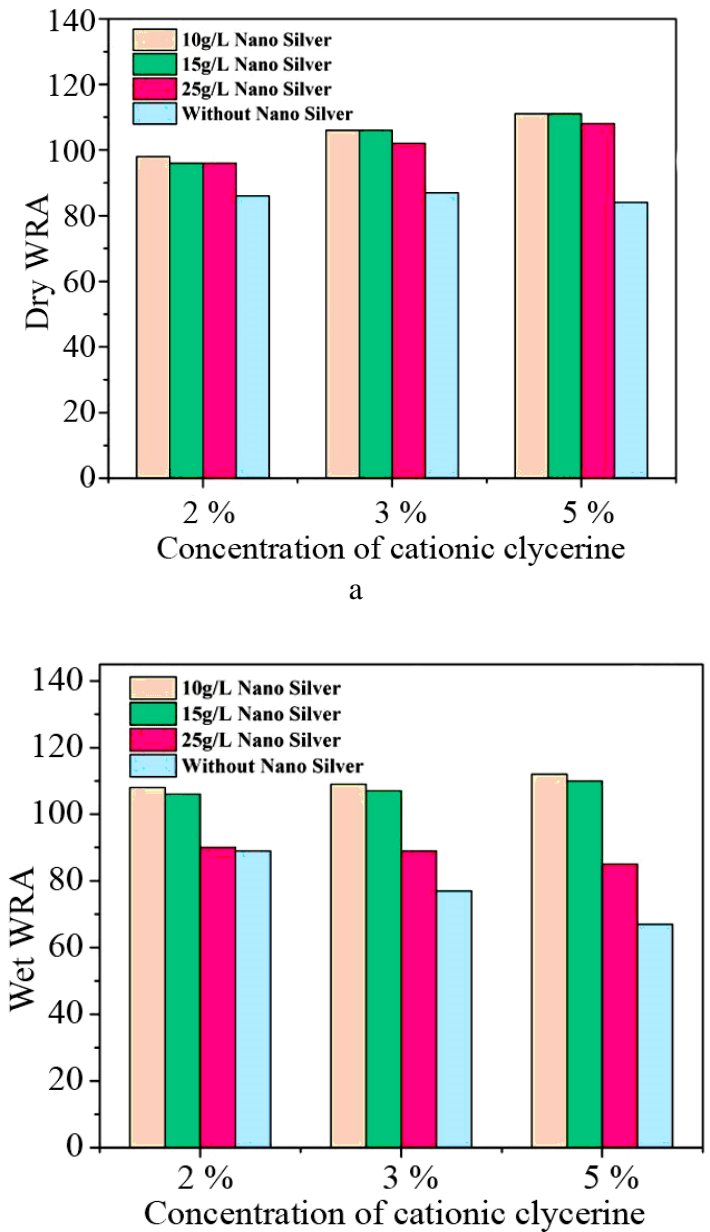

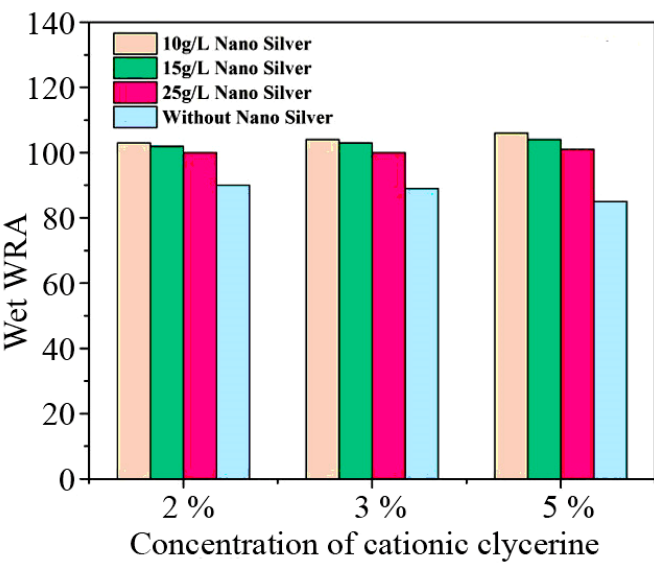

b

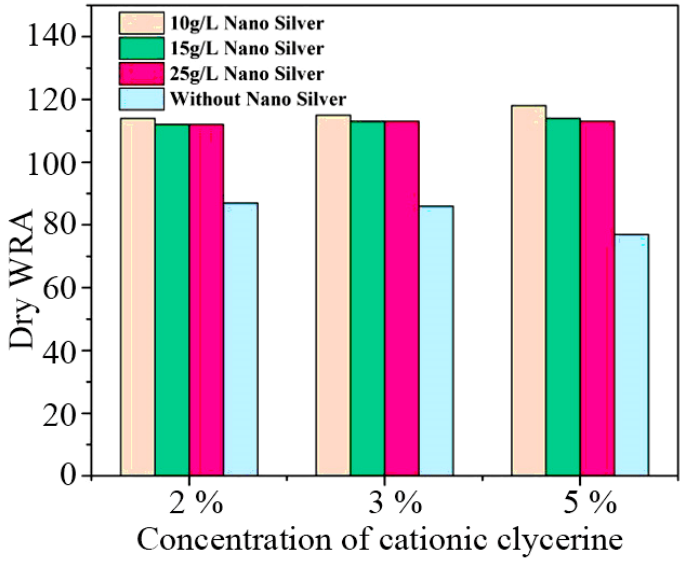

d

Figure 2 - The study of the effect of cationic glycerine concentration: a - Dry WRA of Pad Dry Cure Samples with Appretan N 92111 with Varying Concentration of CG and Nano silver; b - Wet WRA of Pad Dry Post Cure Samples without Appretan N 92111 with Varying Concentration of CG and Nano silver; c - Wet WRA of Pad Dry Post Cure Samples with Appretan N 92111 with Varying Concentration of CG and Nano silver; d - Wet WRA of Pad Dry Cure Samples without Appretan N 92111with Varying Concentration of CG and Nano silver

Absorbency. Absorbency was determined for the fabric treated with cationic glycerine with varying concentration $2 \%, 3 \%$ and $5 \%$ and Nano-Silver application with Binder and without Binder. It has been observed that the samples which were processed by pad dry post cure method, after the process of ionic cross-linking i.e. application of cationic glycerine on the carboxymethylated fabric shows a high absorbency then the fabric which was cured after the ionic cross-linking. The Pad dry post cure results are shown in Figure $3 \mathrm{~b}$ and Figure $3 \mathrm{c}$ whereas the pad dry cure results are mentioned in Figure 3d and Figure 4a. So it can be assessed that the pad dry cure process effect absorbency the negative way hence decreasing the absorbency of the treated fabric.

It was evaluated that cationic glycerine concentration has considerable effects on absorbency of fabric. It was determined that $2 \%$ cationic glycerine concentration gives better absorbency as compared to $3 \%$ and $5 \%$ Figure $3 \mathrm{~d}$ cationic glycerine concentration. Glycerine is organic in nature so increasing the concentration of cationic glycerine possesses negative effect on absorbency. It was investigated that application of Nano silver without Appretan N 92111 (binder) shows better results. The samples which were treated together with Appretan N92111 (binder) gives less absorbency Figure $3 \mathrm{~b}$ and Figure $3 \mathrm{~d}$.
Flexural Rigidity. Flexural Rigidity was determined for the fabric treated with cationic glycerine with varying concentration i.e. $2 \%, 3 \%$ and $5 \%$ and Nano-Silver application with Binder and without Binder. It has been observed that the samples which were just dried after the process of ionic cross-linking i.e. application of cationic glycerine on the carboxymethylated fabric shows a slightly greater stiffness then the fabric which were cured after the ionic cross-linking Table 3 and Table 4. The cross-linked samples exhibited more or less the same bending length value however it was observed that increasing the concentration of cationic glycerine does not have significant effect on bending length value. The cross-linked samples exhibited a range of bending lengths from 2.3 to $2.6 \mathrm{~cm}$ (increase of $19 \%$ ) to the original value of $2.1 \mathrm{~cm}$. the value can be seen in the Table 3 and Table 4 given below.

The samples which treated together with binder shows slightly greater stiffness value than the samples which were treated without binder i.e. Appretan N 92111. So it has been practically observed that the stiffness increases due to the binder. It was also experimented that Nano silver concentration also does not have a significant effect on the stiffness of the samples however there is slightly decrease in stiffness value was observed with high concentration of Nano silver i.e. $25 \mathrm{~g} / \mathrm{L}$. 

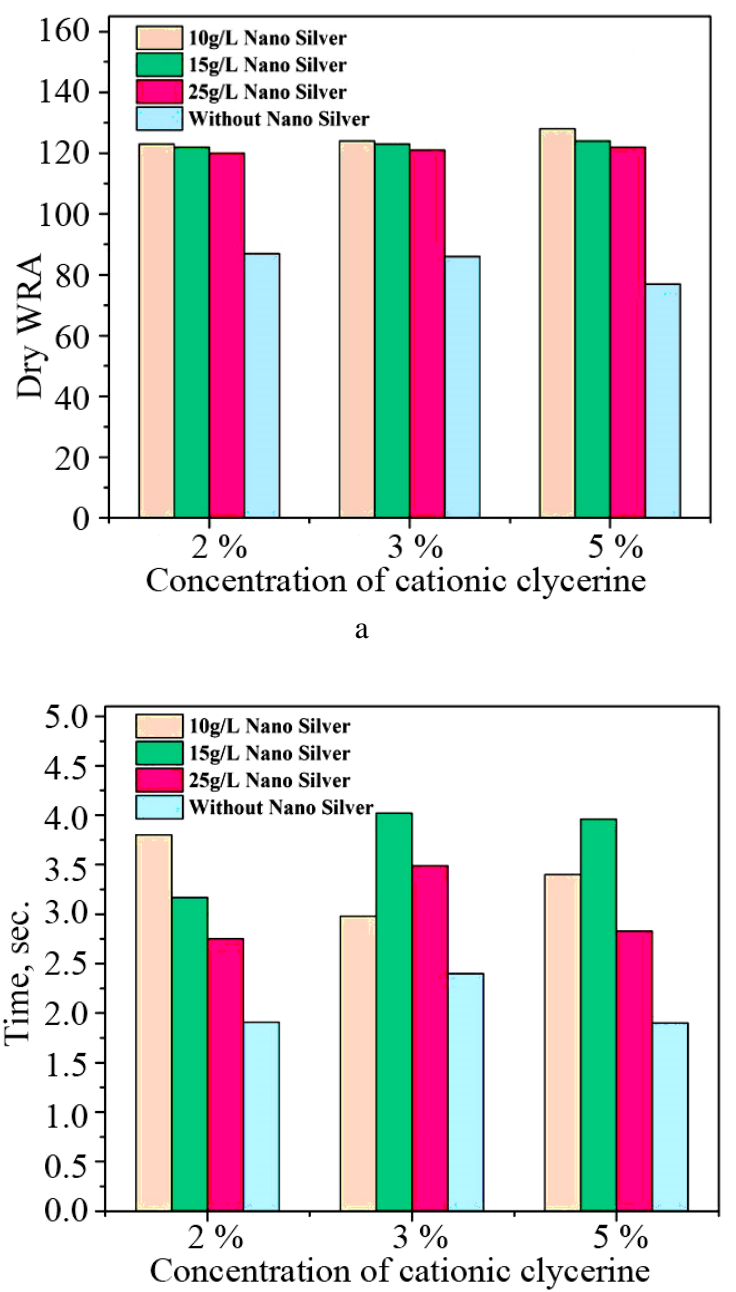

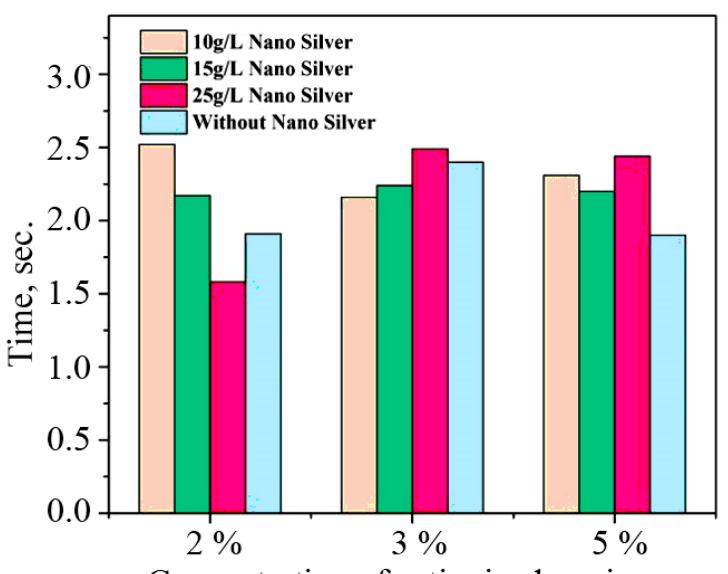

Concentration of cationic clycerine

$\mathrm{b}$

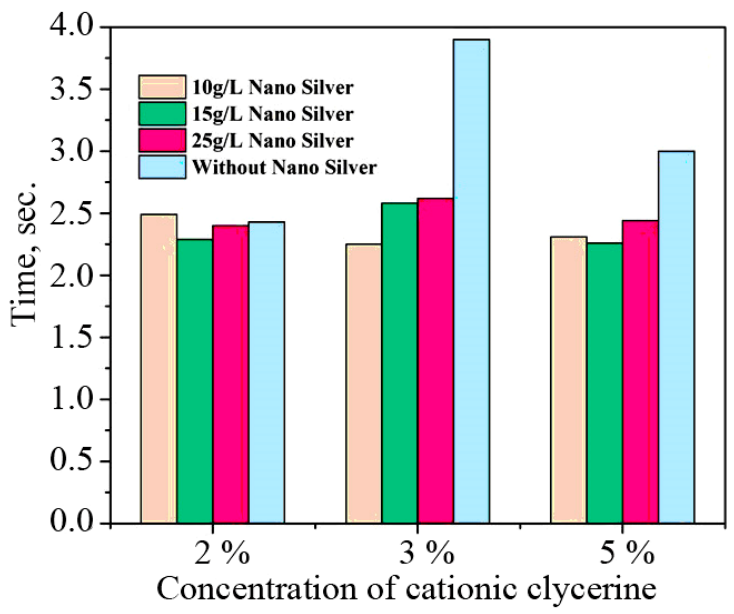

d

Figure 3 - The study of the samples absorbency: a - Wet WRA of Pad Dry Cure Samples with Appretan N 92111with Varying Concentration of CG and Nano silver; b - Absorbency of Pad Dry Post Cure Samples without Appretan N 92111with Varying Concentration of CG and Nano silver; c - Absorbency of Pad Dry Post Cure Samples with Appretan N 92111 with Varying Concentration of CG and Nano silver; d - Absorbency of Pad Dry Cure Samples without Appretan N 92111 with Varying Concentration of CG and Nano silver

Table 1 - CIE Whiteness for Pad Dry Cure and Pad Dry Post Cure Samples without Appretan N 92111 with Varying Concentration of $\mathrm{Cg}$ and Nano silver

\begin{tabular}{lllllll}
\hline Nano Silver with & \multicolumn{5}{l}{ Pad dry post cure } & \multicolumn{3}{l}{ Pad dry cure } \\
\cline { 2 - 7 } Appretan N 92111 & $2 \%$ CG & 3\% CG & $5 \%$ CG & $2 \%$ CG & $3 \%$ CG & $5 \%$ CG \\
\hline $10 \mathrm{~g} / \mathrm{L}$ & 62.75 & 61.67 & 64.27 & 61.12 & 59.98 & 60.99 \\
$15 \mathrm{~g} / \mathrm{L}$ & 65.48 & 64.32 & 62.64 & 60.89 & 62.10 & 55.08 \\
$25 \mathrm{~g} / \mathrm{L}$ & 62.02 & 62.54 & 64.18 & 61.42 & 61.71 & 59.13 \\
\hline
\end{tabular}

Table 2 - CIE Whiteness for Pad Dry Cure and Pad Dry Post Cure Samples with Appretan N 92111 with Varying Concentration of $\mathrm{Cg}$ and Nano silver

\begin{tabular}{lllllll}
\hline Nano Silver without & \multicolumn{5}{l}{ Pad dry post cure } & \multicolumn{5}{l}{ Pad dry cure } \\
\cline { 2 - 7 } Appretan N 92111 & $2 \%$ CG & $3 \%$ CG & $5 \%$ CG & $2 \%$ CG & $3 \%$ CG & $5 \%$ CG \\
\hline $10 \mathrm{~g} / \mathrm{L}$ & 63.21 & 63.25 & 65.25 & 62.62 & 59.67 & 58.94 \\
$15 \mathrm{~g} / \mathrm{L}$ & 65.09 & 65.53 & 63.39 & 63.86 & 63.42 & 61.99 \\
$25 \mathrm{~g} / \mathrm{L}$ & 64.65 & 64.82 & 62.01 & 65.57 & 60.73 & 62.82 \\
\hline
\end{tabular}

Tensile Strength. Tensile strength was determined for the fabric treated with cationic glycerine with varying concentration $2 \%, 3 \%$ and $5 \%$ and Nano-Silver application with Binder and without Binder. It was analyzed that the samples which are pad dry cure have the negative effect on the concentrations of the cationic glycerine. It means that the tensile strength of the fabric is decreased with the increase in the concentration of cationic glycerine. While in the samples which were pad dry post cure, it was observed that the as the concentration of the cationic glycerine was raised, it has the affirmative effect on the tensile strength of the fabric having increased tensile strength with high concentration of cationic glycerine given in Figure $4 \mathrm{c}$ and Figure 5b.The tensile strength of the fabric which was treated with $2 \%$ cationic glycerine was founded to be slightly higher than the fabrics which were treated with $3 \%$ and $5 \%$ cationic glycerine solution. The 
strength does not seem to be that much affected by varying the concentration of cationic glycerine whereas the other factors like parameters and variation in Nano silver does affect the strength of the fabric Figure 4d.

As in the earlier discussion in other test methods, it was discussed that the binder supports ionic cross-links though making fabric stiff but with the addition of binder the ionic cross-link of the fabric is strong which have assenting impact on the fabric's physical properties. With the addition of the binder the tensile strength of the fabric is enhanced though with the variation of Nano silver quantity in the samples the value of tensile strength varies. The tensile strength of the fabric which have been treated with Nano silver addition of binder have better tensile strength then the fabric which are treated with Nano silver without binder addition as mentioned in Figure $4 c$ and Figure $5 b$. Tensile strength of the ionic cross-link fabric which was treated with $10 \mathrm{~g} / \mathrm{L}$ Nano silver with and without binder has comparatively better tensile strength then the other quantities of Nano silver with and without binder.

Abrasion. Abrasion was determined for the fabric treated with cationic glycerine with varying concentrations of $2 \%$, $3 \%$ and $5 \%$ and Nano-Silver application with Binder and without Binder. In varying the parameters, it was observed that, the samples which were processed just pad dry post cure have less abrasion giving good resistance to abrasion while
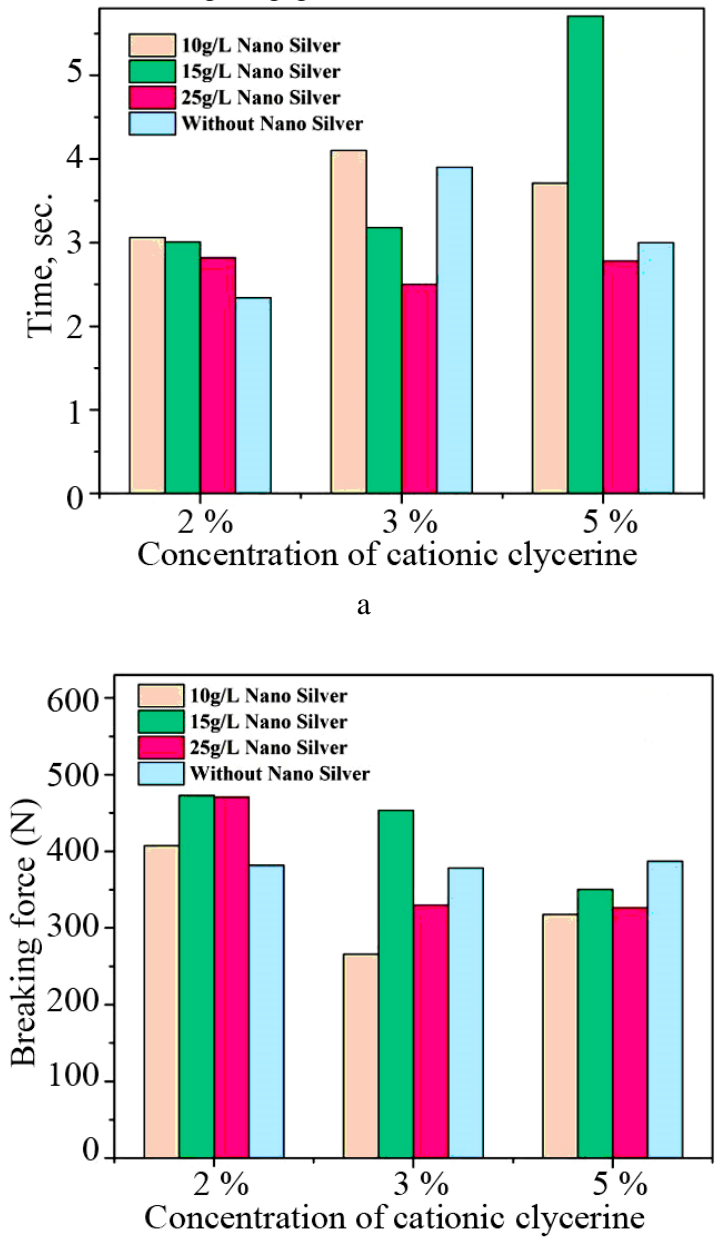

the samples which were processed pad dry cure have not as much good abrasion resistance compared to other process (Table 5). It was also accessed that in the fabric which was pad dry pad cured shows the increase in the abrasion resistance as the concentration of the CG was increased such as $3 \%$ and $5 \%$ while in the process of pad dry cure the fabric shows the decrease in abrasion resistance when there is increment in the concentration of glycerine. It means that the samples have increased weight when they are ionic cross-linked and resistant to the untreated samples.

When there was variation in the concentration of cationic glycerine, the samples which were treated with $2 \% \mathrm{CG}$ have greater abrasion resistance then the samples which were treated by $3 \% \mathrm{CG}$ and $5 \%$ CG comparing Table 5 and Table 6 . The ionic cross-link of $2 \% \mathrm{CG}$ with $1 \mathrm{M}$ of sodium salt of chloroacetic acid is the better combination for better abrasion resistance of the fabric. Although there is an effect on the abrasion resistance when there is change of parameters but that's in other case. The fabric which is ionic cross-linked have less abrasion resistance which means it gives better results than Durable Press finished fabric. With the addition of binder, the cross-link becomes stronger and enhance the abrasion resistance giving better result Table 5 than the fabric in which binder is not added with Nano silver Table 6. Although the different concentrations of Nano silver have a slight change in the abrasion resistance, just making sure its presentation in the fabric.

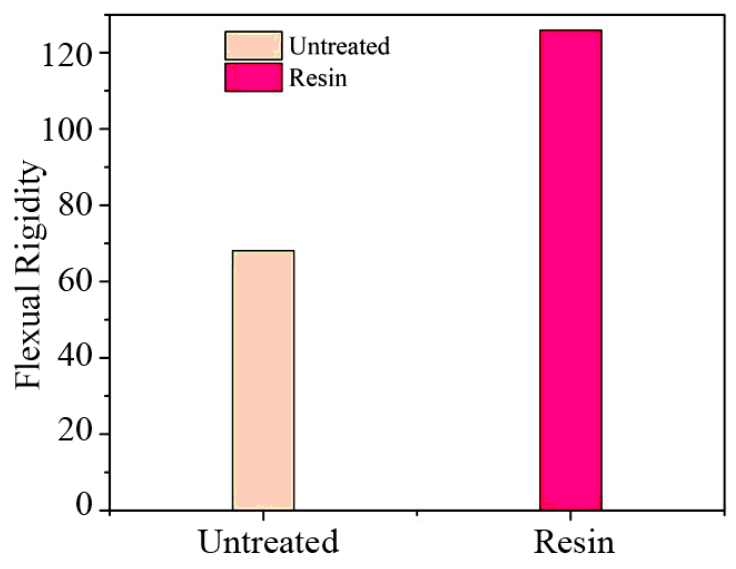

b

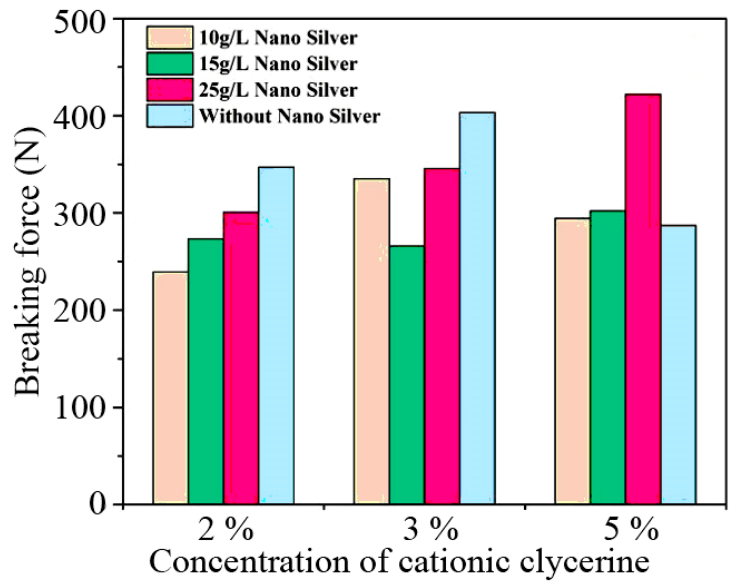

d

Figure 4 - The study of the Effect of Pad Dry Cure and Pad Dry Post Cure Method: a - Absorbency of Pad Dry Cure Samples with Appretan N 92111 with Varying Concentration of CG and Nano silver; b - Effect of Pad Dry Cure and Pad Dry Post Cure Method on Stiffness; c - Tensile Strength of Pad Dry Cure Samples with Appretan N 92111 with Varying Concentration of CG and Nano silver; d - Tensile Strength of Pad Dry Post Cure Samples with Appretan N 92111 with Varying Concentration of CG and Nano silver 
Table 3 - Flexural Rigidity of Pad Dry Cure and Pad Dry Post Cure Samples with Appretan N 92111 with Varying Concentration of CG and Nano silver

\begin{tabular}{lllllll}
\hline Nano Silver without & \multicolumn{5}{l}{ Pad dry post cure } & \multicolumn{3}{l}{ Pad dry cure } \\
\cline { 2 - 7 } Appretan N 92111 & $2 \%$ CG & $3 \%$ CG & $5 \%$ CG & $2 \%$ CG & $3 \%$ CG & $5 \%$ CG \\
\hline $10 \mathrm{~g} / \mathrm{L}$ & 112.42 & 112.41 & 96.96 & 88.44 & 112.44 & 112.44 \\
$15 \mathrm{~g} / \mathrm{L}$ & 112.43 & 112.44 & 112.44 & 88.44 & 112.44 & 112.44 \\
$25 \mathrm{~g} / \mathrm{L}$ & 112.44 & 112.44 & 99.96 & 88.44 & 99.96 & 96.96 \\
\hline
\end{tabular}

Table 4 - Flexural Rigidity of Pad Dry Cure and Pad Dry Post Cure Samples without Appretan N 92111 with Varying Concentration of CG and Nano silver

\begin{tabular}{lllllll}
\hline Nano Silver without & \multicolumn{5}{l}{ Pad dry post cure } & \multicolumn{5}{l}{ Pad dry cure } \\
\cline { 2 - 7 } Appretan N 92111 & $2 \%$ CG & $3 \%$ CG & $5 \%$ CG & $2 \%$ CG & $3 \%$ CG & $5 \%$ CG \\
\hline $10 \mathrm{~g} / \mathrm{L}$ & 112.44 & 112.44 & 112.44 & 88.44 & 112.44 & 96.96 \\
$15 \mathrm{~g} / \mathrm{L}$ & 88.44 & 112.44 & 88.44 & 88.44 & 99.965 & 88.44 \\
$25 \mathrm{~g} / \mathrm{L}$ & 112.44 & 99.96 & 77.83 & 88.44 & 88.44 & 88.44 \\
\hline
\end{tabular}

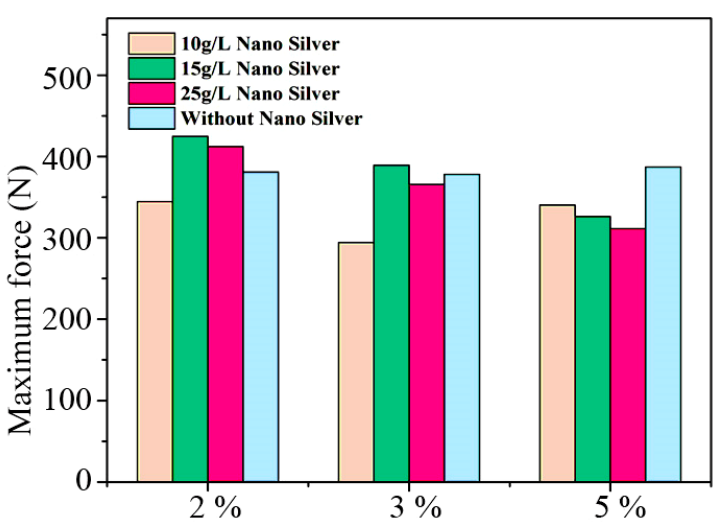

Concentration of cationic clycerine

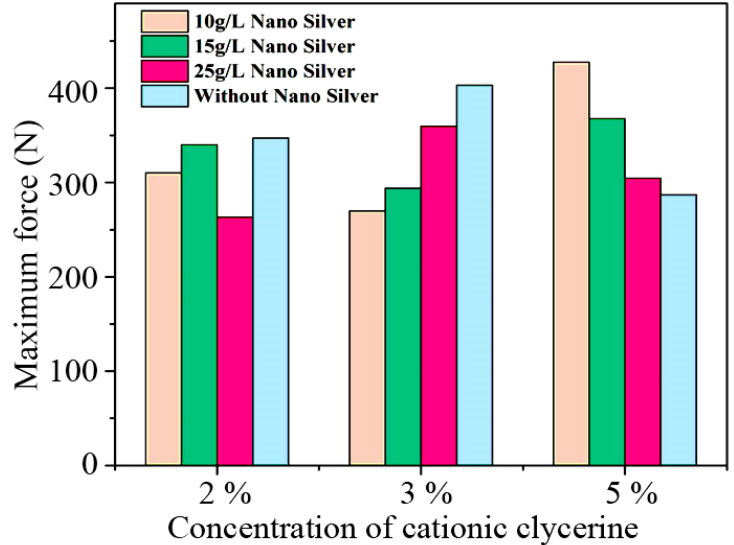

b

Figure 5 - The study of the samples tensile strength: a - Tensile Strength of Pad Dry Post Cure Samples without Appretan N 92111 with Varying Concentration of CG and Nano silver; b - Tensile Strength of Pad Dry Cure Samples without Appretan N 92111 with

Varying Concentration of CG and Nano silver

Table 5 - Abrasion of Pad Dry Cure and Pad Dry Post Cure Samples with Appretan N 92111 with Varying Concentration of CG and Nano silver

\begin{tabular}{lllllll}
\hline Nano Silver without & \multicolumn{7}{l}{ Pad dry post cure } & \multicolumn{7}{l}{ Pad dry cure } \\
\cline { 2 - 7 } Appretan N 92111 & $2 \%$ CG & $3 \%$ CG & $5 \%$ CG & $2 \%$ CG & $3 \%$ CG & $5 \%$ CG \\
\hline $10 \mathrm{~g} / \mathrm{L}$ & 1.20 & 1.12 & 1.06 & 1.55 & 0.97 & 0.84 \\
$15 \mathrm{~g} / \mathrm{L}$ & 1.44 & 0.50 & 1.59 & 0.87 & 0.32 & 1.85 \\
$25 \mathrm{~g} / \mathrm{L}$ & 1.32 & 0.67 & 1.19 & 0.64 & 1.54 & 0.52 \\
\hline
\end{tabular}

Table 6 - Abrasion of Pad Dry Cure Samples without Appretan N 92111 with Varying Concentration of CG and Nano silver

\begin{tabular}{lllllll}
\hline Nano Silver without & \multicolumn{5}{l}{ Pad dry post cure } & \multicolumn{3}{l}{ Pad dry cure } \\
\cline { 2 - 7 } Appretan N 92111 & $2 \%$ CG & $3 \%$ CG & $5 \%$ CG & $2 \%$ CG & $3 \%$ CG & $5 \%$ CG \\
\hline 10 g/L & 1.90 & 1.49 & 1.35 & 2.03 & 1.93 & 0.96 \\
15 g/L & 1.43 & 1.52 & 2.14 & 0.83 & 1.07 & 1.82 \\
25 g/L & 1.34 & 0.97 & 1.23 & 1.32 & 0.49 & 2.01 \\
\hline
\end{tabular}

\section{Conclusion.}

With the ionic cross-linking, the dry WRA was achieved an optimum of $118^{\circ}$ and wet WRA up to $128^{\circ}$ with increased fabric strength and whiteness.

In addition to ionic cross-linking fabric was treated with Nano silver. It was analyzed that fabric with addition to binder gives rise to WRA of the samples but some of the other properties were effected with the addition of binder such as stiffness and whiteness while in the samples in which binder was not added shows a small change in WRA of the samples but other properties of stiffness and whiteness were greater than that of the samples treated with addition of binder.
Based on the results it was concluded that the fabric can be optimized first with ionic cross-link method and then it can be treated with the antimicrobial making the fabric cleaner and hygienic. This fabric treatment provides the necessary characteristics and is safe for the health of the people who use it.

\section{Acknowledgements.}

The authors received no financial support for the research, authorship, and/or publication of this article.

Conflicts of Interest.

The authors declared no potential conflicts of interest with respect to the research, authorship, and/or article publication. 


\section{REFERENCES}

1. Chen, W., Lickfield, G.C., Yang, C.Q. (2004). Molecular modeling of cellulose in amorphous state part II: effects of rigid and flexible crosslinks on cellulose. Polymer, 45(21), 7357-7365

2. Lacasse, K., Baumann, W. (2012). Textile Chemicals: Environmental data and facts. Springer Science \& Business Media.

3. Carr, C. (Ed.). (2012). Chemistry of the textiles industry. Springer Science \& Business Media, 4.

4. Schindler, W.D., Hauser, P.J. (2004). Chemical finishing of textiles. Elsevier.

5. Hashem, M., Hauser, P., Smith, B. (2003). Wrinkle recovery for cellulosic fabric by means of ionic crosslinking. Textile Research Journal, 73(9), $762-766$.

6. Hashem, M., Hauser, P., Smith, B. (2003). Reaction efficiency for cellulose cationization using 3-chloro-2-hydroxypropyl trimethyl ammonium chloride. Textile research journal, 73(11), 1017-1023.

7. Hashem, M., Hauser, P., Smith, B. (2003). Wrinkle recovery for cellulosic fabric by means of ionic crosslinking. Textile Research Journal, 73(9), $762-766$.

8. Rupin, M. (1976). Dyeing with Direct and Fiber Reactive Dyes. Textile Chemist \& Colorist, 8, 9-28.

9. Wu, T.S., Chen, K.M. (1993). New cationic agents for improving the dyeability of cellulose fibres. Part 2 - pretreating cotton with

polyepichlorohydrin - amine polymers for improving dyeability with reactive dyes. Journal of the Society of Dyers and Colourists, 109 (4), 153-158.

10. Hauser, P.J., Tabba, A.H. (2001). Improving the environmental and economic aspects of cotton dyeing using a cationised cotton. Coloration Technology, 117(5), 282-288.

11. Hauser, P.J., Tabba, A.H. (2002). Dyeing Cationic Cotton with Fiber Reactive Dyes: Effect of Reactive Chemistries. AATCC review, 2(5).

12. Tabba, A H., Hauser, P. (2000). Effect of Cationic Pretreatment on Pigment Printing of Cotton Fabric. Textile Chemist \& Colorist \& American Dyestuff Reporter, 32(2).

13. Kim, Y.H., Choi, H.M., Yoon, J.H. (1998). Synthesis of a quaternary ammonium derivative of chitosan and its application to a cotton antimicrobial finish. Textile Research Journal, 68(6), 428-434.

14. Hauser, P.J. (2000). Reducing Pollution and Energy Requirements in Cotton Dyeing. Textile Chemist \& Colorist \& American Dyestuff Reporter, $32(6)$.

15. Sahin, U.K., Gursoy, N.C., Hauser, P., Smith, B. (2009). Optimization of ionic crosslinking process: an alternative to conventional durable press finishing. Textile Research Journal, 79(8), 744-752.

16. Wasif, A.I., Laga, S.K. (2009). Use of nano silver as an antimicrobial agent for cotton. Autex Research Journal, 9(1), 5-13.

А. М. Пирзада, С. Вамболь, З. Кхатри, А. Азиз, Н. А. Самоон, С. Шаикх, М. Али, С. Сикандар

ГИГИЕНА И ОХРАНА ЗДОРОВЬЯ. ИССЛЕДОВАНИЕ УГЛА ВОССТАНОВЛЕНИЯ СКЛАДОК (WRА) ТКАНИ, ОБРАБОТАННОЙ НАНОСЕРЕБРОМ

Постоянное использование устойчивых к складкам целлюлозных тканей в профессиональной и повседневной жизни может отрицательно сказаться на состоянии здоровья. Ведь пары формальдегида вызывают аллергию (постоянный кашель, раздражение глаз, носа и горла), нарушения сна, головные боли и т. д., и тем самым представляют большую опасность. В этом исследовании была предпринята попытка стабилизации устойчивости ткани к складкам путем образования ионных связей вместо ковалентных. И это основная цель исследования. Для исследования была использована промышленно обработанная и отбеленная 100 \%-ная чистая хлопчатобумажная ткань плотностью 110 г/м² и различные химические вещества. Было обеспечено приготовление катионного глицерина, карбоксиметилирование отбеленной ткани и нанесение антимикробных покрытий на сшитую ионами ткань. Измерения были проведены для определения угла восстановления складок (WRA), влагопоглащения, белизны, жесткости при изгибе, истирания, прочности на разрыв. Угол восстановления складок измеряли стандартным методом ААТСС 66 (вариант 2). Метод испытания ААТСС 79-2000 был использован для проверки впитывающей способности ткани. Индекс белизны CIE определяли с использованием спектрофотометра Xrite Color Еуе 7000А. Жесткость при изгибе измеряли посредством испытательной консоли методом ASTM D-1388. Истирание ткани проверяли в соответствии со стандартным методом стойкости к истиранию текстильной ткани ASTM 4966 на устройстве для абразивного износа Martindale М235. Механическая прочность ткани измерялась по стандартному методу ASTM D-5034. Благодаря образованию ионных поперечных связей WRA сухой ткани достиг оптимального значения $118^{\circ}$, а влажной - до $128^{\circ}$ с повышенной прочностью и белизной ткани. В дополнение к образованию ионных поперечных связей ткань была обработана наносеребром. На основании полученных результатов был сделан вывод, что сначала ткань можно оптимизировать методом ионной сшивки, а затем обработать антимикробным средством, что делает ткань более чистой и гигиеничной. Такая обработка ткани обеспечивает необходимые характеристики и безопасна для здоровья людей, которые ее используют.

Ключевые слова: гигиена и охрана здоровья; безопасность текстильных изделий; угол восстановления складок; катионный глицерин; метод ионных поперечных связей; обработка наносеребром. 